\title{
"Men nu fick man planera om och i den planeringen fick jag vara med!" Verksamhetsförlagt lärande i yrkeslärarutbildningen när undervisningen går över till distans
}

\author{
'Now we' ve got to re-plan together!' \\ Workplace-based learning in vocational teacher education \\ in times of a transition to online instruction \\ Martina Wyszynska Johansson, \\ Ellinor Dyne \& Susanne Gustavsson
}

Göteborgs universitet, Sverige (martina.wyszynska.johansson@gu.se)

\begin{abstract}
The article explores the effects of the transition to distance education due to the Covid19 pandemic on vocational teacher students' workplace-based learning in a vocational teacher programme. Two practices are explored, that is, the instruction practices by prospective teachers and supervision. The theory of practice architecture is used to explain how the two practices interplay with one another in the common project of learning to become a vocational teacher. A web survey is utilised to gain both the students' and the supervisors' experiences. The main findings are 1) re-definition of pupil participation and activity as a touching base for supervision, and 2) expanded notion of supervision grounded in a more equal and complementary relationship between the student and the teacher supervisor. A call for an updated in-service supervision training as part of the vocational teacher programme and to strengthen vocational teacher education as a whole is put forth.
\end{abstract}

Keywords: vocational teacher education, distance education, supervision, workplacebased learning 
"Men nu fick man planera om och i den planeringen fick jag vara med!"

\section{Introduktion}

Under vårterminen 2020 förändrades villkoren för utbildningar på grund av pågående pandemi. Undervisning i svensk gymnasieskola, kommunal vuxenutbildning och högre utbildning genomfördes från mitten av mars, förutom vissa undantag på distans. Omställningen gjordes med kort varsel och därmed utan möjlighet till förberedelser. För studenter i verksamhetsförlagd utbildning (VFU) i yrkeslärarutbildningen innebar förändringen att studenten kunde vara på plats i VFU-skolan, men att undervisningen i VFU i huvudsak genomfördes på distans. Undervisning i yrkesutbildning och därmed också VFU i yrkeslärarutbildningen påverkas när aspekter som undervisningens plats, resurser och olika former av interaktion ändras. Den undervisningspraktik som studenter var förberedda för och inställda på och som VFU-handledare var vana vid förändrades, vilket därmed även ändrade förutsättningarna för studentens utbildning och VFU-handledarens uppdrag. Studien belyser omställningens betydelse för studentens professionsutveckling i utbildningens verksamhetsförlagda delar.

VFU i svensk yrkeslärarutbildning omfattar en tredjedel av programmet och innebär att studenten under handledning planerar, genomför och utvärderar undervisning samt medverkar mer eller mindre aktivt i VFU-handledarens övriga uppdrag och arbetsuppgifter. Betoningen på utbildning i yrkespraktiken samt relationen erfarenhet, beprövad erfarenhet och vetenskaplig grund formar studentens, VFU-handledarens och utbildningens roll och uppdrag (Utbildningsdepartementet, 1999, 2008). De verksamhetsförlagda studierna ska ge studenten möjlighet att utveckla viss förtrogenhet för yrkeslärarens arbetsuppgifter. VFU-perioden är således väsentlig för studentens möjlighet att öva och prövas i yrkets både planerade och situationsstyrda praktik. Det ställer krav på vad som erbjuds studenten i den aktuella kontexten och vilken betydelse detta kan få för den professionella utvecklingen under yrkeslärarutbildningen.

Vissa studenter gör sin VFU i olika typer av distansförlagd vuxenutbildning. Men merparten av VFU-skolorna har skolförlagd yrkesutbildning eller lärlingsutbildning med skolförlagd undervisning. Under vårterminen 2020 förflyttades undervisningen med några undantag, till mer eller mindre välbekanta digitala plattformar eller system. Yrkesutbildningens undervisningspraktik som vanligen kännetecknas av en variation av miljöer och former, blev avgränsad till den typ av undervisning som kunde göras möjlig på distans. Undervisningen innebar således förändrade villkor för yrkesutbildningens elever, lärare och för studenter i VFU.

Under en lång tid har det funnits en ambition att använda digitala verktyg $\mathrm{i}$ undervisning på alla utbildningsnivåer. Nationella initiativ och projekt både inom grundläggande utbildning och lärarutbildning (t.ex. Regeringen, 2017; Sveriges kommuner och regioner, 2019; Sveriges riksdag, 2015) synliggör det politiska och samhälleliga intresset att utveckla digital kompetens för undervisning, 
och som ett viktigt kunskapsinnehåll i utbildning. Samtidigt är frågor om de digitala verktygens plats, funktion och betydelse i undervisningen föremål för en kritisk diskussion (Palak \& Walls, 2014; Player-Koro, 2018; Williamson m.fl., 2020). Williamson m.fl. (2020) sammanfattar fyra kritiska aspekter i samband med den påtvingade distansundervisningen:

- de så kallade edtech-företagens dominerande position när utbildningen blir beroende av digitala verktyg,

- likvärdig utbildning när förutsättningarna i hemmet är en avgörande faktor,

- skolans roll som utbildningsmiljö när undervisningen flyttas till andra miljöer

- den påtvingade distansundervisningens öppningar för olika intressen, experiment och undersökningar som kan utmana uppfattningen om hur framgångsrik utbildning kan och bör bedrivas.

Oavsett skäl till användning av digitala verktyg finns det flera intressenter och förutsättningar som involveras. Dessa exempel på kritiska aspekter (Williamson m.fl., 2020) kan relateras till studentens utbildning i VFU och VFU-handledares yrkespraktik samt handledning där befintliga digitala verktyg, men också lösningar av identifierade utmaningar blir en del av den gemensamma praktiken. Yrkeslärarstudenten i VFU blev under våren 2020 direkt berörd av de förändrade villkoren för undervisning och övrig kontakt med elever, vilket då också påverkade handledningspraktiken. Omställningen skapar intresse för hur den förändrade undervisningen i yrkesutbildning får betydelse för genomförandet av VFU. Föreliggande artikel studerar de utmaningar och möjligheter som identifieras när förutsättningar och villkor för VFU ändras.

\section{Syfte}

För att utveckla lärarkompetens i samband med VFU behöver studenten få direkt tillgång till VFU-handledarens praktik. Via handledning kan studenten även få syn på och ges möjlighet att diskutera bakgrund och argument för didaktiska val, samt få återkoppling på sin egen prestation. Under yrkeslärarutbildningen formar och formas studenten mot en grundläggande yrkesläraridentitet och skicklighet, under förutsättning att det finns goda möjligheter till övning och uppföljning av såväl undervisning som övriga arbetsuppgifter som kan relateras till uppdraget som yrkeslärare. Syftet med studien är att undersöka studenters möjligheter att utveckla yrkeskunnande när undervisningen i VFU-skolan ställs om till distansundervisning och de givna förutsättningarna för undervisning ändras. 
"Men nu fick man planera om och i den planeringen fick jag vara med!"

Frågeställningar:

- Hur påverkas studenternas undervisningspraktik i samband med att undervisningen i yrkesutbildning blir distansbaserad?

- Hur anpassar VFU-handledare sin handledning när undervisningen i yrkesutbildningen blir distansbaserad?

\section{Forskningsbakgrund}

Forskningsbakgrunden tar utgångspunkt i studiens två frågeställningar om hur studentens egen undervisning samt handledning i VFU påverkas när undervisningen i yrkesutbildningen övergår till distans. Den specifika situationen under 2020 har skapat ett intresse för studier om distansundervisning, vilket gör att vi i huvudsak avgränsar oss till forskning som direkt anknyter till distansundervisning på grund av pandemin. Då studiens kontext är yrkeslärarutbildning och VFU är det relevant att både använda studier som belyser gymnasial utbildning och lärarutbildning. Inledningsvis behandlas övergripande digitaliseringens givna plats i utbildningar, men också effekter och konsekvenser av intentionen att göra digitala verktyg till en given undervisningsresurs. Därefter redovisas studier om övergången till distansundervisning med anledning av pandemin. Avslutningsvis fokuseras VFU i samband med distansundervisningen samt relationen mellan lärarutbildningens två utbildningspraktiker.

Digitalisering är numera ett institutionaliserat begrepp i utbildningskontexter oavsett nivå. All undervisning och utbildning förutsätts använda olika former av digitala verktyg. Bakgrunden är den digitala teknikens utveckling generellt, och att även utbildning behöver använda de möjligheter som erbjuds med syftet att underlätta, tillgängliggöra och effektivisera lärandeprocesser. Detta har fått betydelse för det utbud av digitala verktyg som finns tillgängliga inom utbildning (Bergdahl \& Nouri, 2020). Utöver digitala verktyg för undervisning innehåller yrkesutbildning specifika kunskapsområden relaterat till digital teknik i den yrkesverksamhet som utbildningen riktas mot. Digital kompetens är dessutom en av EU:s så kallade nyckelkompetenser (Utbildningsutskottet, 2016), vilket kan översättas till generella kompetenser till exempel i en yrkesutbildning eller lärarutbildning.

En parallell och mer kritisk diskussion belyser hur undervisningens praktik kan ses som underordnad de digitala verktyg som erbjuds i en utbildning. Den marknad som utvecklar och producerar digitala verktyg kan i hög grad ha mer fokus på att konkurrera och att attrahera presumtiva kunder, än på lärarens och undervisningens behov. Vidare saknas ofta kunskap om undervisningspraktiken och de behov som finns där. Marknaden har således en viss makt över undervisningen, vilket därmed också får konsekvenser både för lärare och elever (Andreasson \& Dovermark, 2013; Player-Koro, 2018; Player-Koro m.fl., 2018). Samtidigt skapar utvecklingen inom det digitala området nya typer av läromedel och nya möjligheter (t.ex. Enochsson m.fl., 2020; Gustavsson m.fl., 2020). 
Ytterligare en utgångspunkt i diskussionen om digitalisering är den uttalade bristen på lärares kompetens och i vissa fall låga intresse för att använda digital teknik (Palak \& Walls, 2014). Här beskrivs mer kompetensutveckling som en nödvändig lösning (Sveriges kommuner och regioner, 2019). ^̊ andra sidan har distansundervisningen våren 2020 synliggjort lärares faktiska kompetens samt utmaningar och utvecklingsbehov, men också möjliga förändringar i undervisningspraktiken (Bergdahl \& Nouri, 2020; Stenliden m.fl., 2020). Under den period då all undervisning i svensk gymnasieskola och vuxenutbildning övergick till distans var tidigare upplevda hinder eller utmaningar inte längre aktuella.

En rad internationella och nationella studier (t.ex. Basilaia \& Kvavadze, 2020; Bergdahl \& Nouri, 2020; Sangeeta \& Tandon, 2020; van der Spoel m.fl., 2020; Zhou m.fl., 2020) beskriver sammantaget hur lärare både direkt och efterhand utvecklar distansundervisningen, hur olika typer av digitala verktyg används och hur skolans stödstrukturer har betydelse. En negativ konsekvens som visar sig över tid är dock den sociala interaktionen, främst mellan lärare och elev (Russo \& Benson, 2005; Tu \& Mcissac, 2002; van der Spoel m.fl., 2020). Samtidigt kan lärares interaktion med vissa elever fungera bättre vid distansundervisning (van der Spoel m.fl., 2020). Eleverna avkrävs i högre grad självständighet och eget ansvar för sina studier, samtidigt som utebliven social samvaro och social interaktion med lärare och övriga elever får betydelse för elevernas upplevelser och välmående under den aktuella studietiden (Henning Loeb \& Windsor, 2020).

Vidare finns en kritisk diskussion om hur distansundervisningen har bidragit till förändring av det till synes givna, vilket därmed öppnar för nya frågor och utmaningar. Här diskuteras till exempel skillnaden mellan att elever använder egna digitala verktyg i skolan benämnt som "Bring Your Own Device" (Selwyn m.fl., 2017) och distansundervisningens krav på att använda hemmet som studieplats, vilket leder till "Bring Your Own School Home". Här synliggörs elevers olika förutsättningar för en fungerande studiemiljö i hemmet. Aspekter som likvärdighet och tillgänglighet blir centrala. Vidare sker en upplösning av vad som kan räknas som utbildningstid och fritid, vilket kan påverka elevers strukturering av sin tid, och därmed också förutsättningar för att följa undervisningen. Likaså diskuteras hur de digitala verktyg som är tillgängliga i en utbildningskontext kan användas på ett didaktiskt medvetet sätt för att skapa förutsättningar för lärande och för nödvändig interaktion (Carrillo \& Flores, 2020). När undervisningen genomförs på distans utmanas lärarens didaktiska möjligheter, samtidigt som läraren behöver hitta former som möjliggör undervisning för elevers kunskapsutveckling. Sammanfattningsvis kan distansundervisningen beskrivas som fungerande, men att aspekter som interaktion mellan elev och lärare, elevers olika förutsättningar och likvärdighet är kritiska. $\AA$ andra sidan kan uppfattningen om välfungerande undervisning ställas i relation till de i vissa fall kanske låga förväntningar som skapades med anledning av den snabba omställningen. 
"Men nu fick man planera om och i den planeringen fick jag vara med!"

Yrkeslärarstudenten i VFU blev en aktör i den undervisning som organiserades och genomfördes under perioden med distansundervisning. I en studie från Chile (Sepulveda-Escobar \& Morrison, 2020) om VFU i lärarutbildningen beskrivs interaktionen med elever, samt den snabba förändringen som de största utmaningarna för lärarstudenter. Samtidigt upplever studenter att de utvecklar ny kunskap om digitala verktyg i undervisningen. Detta leder till en diskussion om betydelsen av att lärosätet möter studenters erfarenheter från VFU, både avseende vilken kunskap som kan utvecklas och vad som av olika skäl inte möjliggörs (Kidd \& Murray, 2020) Vidare hävdas betydelsen av att användning av digitala verktyg och distansundervisning implementeras som en given didaktisk aspekt i lärarutbildningar (Kalloo m.fl., 2020; van der Spoel m.fl., 2020). Således beskrivs lärosätets ansvar att både möta samhälleliga behov och krav och att anpassa utbildningen till den lärandemiljö som erbjuds studenten under VFU.

En väsentlig utgångspunkt är att lärarstudenters erfarenheter från VFU sällan går att generaliseras. Erfarenheten är knuten till den specifika yrkespraktik och handledning som studenten kan ta del av. Fransson m.fl. (2019) studerar två lärares användning av och förhållningssätt till digitala verktyg där identifierade skillnader kan förklaras med respektive lärares utvecklade didaktiska strategier och professionella utveckling. Lärarens digitala didaktiska val formas av mer eller mindre medvetna och individuella strategier där flera olika aspekter har betydelse, vilket även får betydelse för det som studenten erbjuds i VFU. Sett till lärares kollegiala arbete synliggörs i en studie om lärarutbildning konsekvensen för lärares kommunikativa praktik när möten enbart kan genomföras som planerade, samt via digitala forum (Sjølie m.fl., 2020). I studien synliggörs utmaningen att kommunicera kollegor emellan och vilken betydelse detta kan få i olika sammanhang, och då framför allt för den mer spontana kommunikationen. Resultatet kan generaliseras till VFU i de fall där lärare arbetar hemifrån, vilket då kan påverka former för handledning. Samtidigt diskuteras hur lärdomar från påtvingad distansundervisning behöver identifieras och relateras till en alltmer hybrid undervisningsmiljö (Adedoyin \& Soykan, 2020). Darling-Hammond och Hyler (2020) diskuterar hur förändrade villkor för undervisning kräver en förnyad syn på lärarrollen, nya former av stödstrukturer, tvärvetenskapliga samarbeten samt utveckling och etablering av undervisningsformer som passar distansundervisning. Det som traditionen erbjuder behöver utmanas och utvecklas. Därmed synliggörs hur både lärare och lärarutbildare behöver ta sig an alternativa undervisningsformer för att skapa förutsättningar för att elever och studenter ska kunna nå kunskapsmålen.

\section{Teorin om praktikarkitekturer}

Studien är praktiknära i den meningen att den behandlar verksamhetsförlagd utbildning där två av oss är delaktiga i rollen som kursledare och lärare i den 
aktuella utbildningens VFU-kurser, och den tredje författaren är representant för en huvudman, och där med särskilt fokus på VFU i lärarutbildning. Vi är således aktörer med olika roller i den kontext där vi samtidigt genomför studien. För att kunna ta distans till egna erfarenheter krävs analysverktyg som bidrar till systematik, struktur och ett kritiskt förhållningssätt. Mot bakgrund av syftet att undersöka förändringar krävs dessutom en teori som både synliggör det som sker och de förutsättningar och villkor som kännetecknar och inramar kontexten. Teorin om praktikarkitekturer (TPA) används inom aktionsforskning för att kritiskt kunna studera och analysera praktiker (Kemmis \& Grootenboer, 2008; Mahon m.fl., 2017), vilka utgörs av specifika sammanhang där något sker. Praktiken är därmed det sammanhang som studeras. Det som sker i denna praktik uttrycks genom säganden (sayings), göranden (doings) och relateranden (relatings). En praktik består av kulturella-diskursiva, materiella-ekonomiska respektive sociala-politiska arrangemang som uttrycks via det semantiska, fysiska respektive sociala. Dessa arrangemang bildar en praktikarkitektur. Praktiken får således en karaktär via de arrangemang som kan identifieras.

Studiens objekt är verksamhetsförlagd utbildning i yrkeslärarprogrammet under en period när utbildningen i VFU-skolor genomförs på distans. Studenters undervisning i VFU och VFU-handledarens handledning är däremot två samspelande praktiker som tillsammans utgör det studerade projektet att lära till yrkeslärare i VFU (Kemmis \& Grootenboer, 2008). Inom dessa praktiker skapas var för sig kulturella-diskursiva, materiella-ekonomiska respektive sociala-politiska arrangemang. VFU förändras från det kända och vardagliga där elever och VFUhandledare är på plats i skolan och där undervisningen bedrivs i olika typer av lokaler anpassade för yrkesutbildning, till att elever och i vissa fall VFU-handledare studerar respektive arbetar hemifrån. Därmed förändras också ingående de sätt som de nämnda praktikerna (att undervisa och handleda) hänger ihop på i projektet att lära till yrkeslärare i VFU.

Studiens praktiker är inte isolerade från andra praktiker eller från omgivande kontext. Rönnerman (2018) beskriver hur det som sker inom en praktik kan relateras till moraliska, politiska eller historiska dimensioner, vilket kan förstås som yttre sammanhang som får betydelse för arrangemanget. Studiens koppling till aktionsforskning är att förutsättningarna för VFU förändrades snabbt, visserligen inte som en vald aktion, men som en särskild händelse som påverkade de aktuella undervisningspraktikerna. Genom att studera vad som sker avseende möjligheter och begränsningar skapas ny kunskap om VFU som kan få betydelse i yrkeslärarutbildningen.

\section{Metod}

Undersökningen genomfördes i juni 2020 med hjälp av två webbenkäter med fem öppna frågor som riktades till yrkeslärarstudenter respektive VFU-handledare 
"Men nu fick man planera om och i den planeringen fick jag vara med!"

som var involverade i VFU-kurser under aktuell termin. Vid utformningen av frågor utgick vi ifrån och använde vår samlade erfarenhet och förståelse för vårt engagemang i yrkeslärarutbildningen genom samverkan mellan lärosäte och huvudman. Frågorna speglade samma innehåll fast utifrån två perspektiv, den handledde och handledaren. Deltagarna ombads delge sina erfarenheter av delaktighet $\mathrm{i}$ undervisning och handledning genom exemplifieringar av huruvida och på vilket sätt förändring hade skett. Bakgrundsfrågor med fasta svarsalternativ (tre respektive fem riktade till studenter och VFU-handledare) efterfrågade information om kontexten för deltagarnas praktik snarare än personliga karaktäristika som till exempel kön eller ålder. Jämförelser inom student- och handledargrupper utifrån olika hänseenden, till exempel progression mellan VFU-kurserna, var således inte studiens avsikt.

I rollen som ansvariga för VFU-kurser hade vi tillgång till listor med studenter, deras VFU-handledare samt kontaktuppgifter. Samtliga informerades om undersökningens syfte, att få kunskap om yrkeslärarstudenters och VFU-handledares erfarenheter vid den övergång till distansundervisning i yrkesutbildningar som rekommenderades den 17 mars 2020 . Vi klargjorde att deltagandet var frivilligt och genom att välja att delta i enkäten gav deltagarna sitt samtycke. Undersökningens urval utgjordes av studenter i de tre VFU-kurser som genomfördes vårterminen 2020, samt deras VFU-handledare i gymnasieskola och gymnasial vuxenutbildning. Sammantaget kontaktades 123 VFU-handledare och 135 studenter. Svarsfrekvensen blev tämligen låg med $43 \%$, respektive $31 \%$ för VFU-handledare och studenter. Urvalet är inte homogent eftersom studenternas förutsättningar är delvis annorlunda i de olika VFU-kurserna. För studenterna i två av de tre kurserna sammanföll införandet av distansundervisning med avslutningsfasen av VFU-kursen. Studenterna i den tredje VFU-kursen berördes i hög grad då kursen löpte över hela terminen. Reguljär distansundervisning förekommer inom vuxenutbildning, vilket berörde ca en fjärdedel av respondenterna. Vid undersökningens tidpunkt var kurserna delvis avslutade och deltagare försäkrades om att inga svar kunde härledas till enskilda individer. Deltagande i enkäten var således frikopplat från undervisning och betygssättning i den för studenten och handledare aktuella VFU-kursen. Författare 1 och 3 är däremot involverade i undervisning på programmet och därför kända för deltagarna, vilket kan indirekt ha inverkan på deltagarnas vilja eller ovilja till att delta i undersökningen.

Enkätsvaren behandlades huvudsakligen kvalitativt och deskriptivt med få procentuella och ungefärliga kvantifieringar för att illustrera. Som första steg i analysen kodade författarna var för sig de öppna enkätsvaren med hjälp av kategorierna "säganden", "göranden" och "relateranden". Både "säganden" och "göranden" formade och omformade relationen mellan handledaren och studenten $i$ en viss praktikekologi, oftast i respons till de omedelbara behoven som den snabba övergången till distansundervisning hade föranlett. För att ett visst fragment av enkätsvar skulle falla under kategorin "relateranden" var villkoret att 
textpartiet innehållsmässigt berörde den ömsesidiga relationen av att handleda och handledas, i synnerhet utifrån social ojämlikhets/jämlikhets perspektiv och handlingsutrymme. Nästa steg fokuserade konstruktion av praktikarkitekturer (PA) (Kemmis m.fl., 2014) i empirin genom gemensamt utforskande av tre typer av arrangemang, dvs. de kulturellt-diskursiva, de materiellt-ekonomiska samt de socialt-politiska (Rönnerman m.fl., 2018, s. 47). Dessa arrangemang uttrycks genom olika konfigurationer av de "säganden", "göranden" och "relateranden" som inledningsvis identifierats.

\section{Resultat}

Inledningsvis presenteras resultatet som besvarar studiens två frågeställningar. Därefter görs en fördjupad analys av hur de två praktikerna, studenters undervisning och handledningen, samspelar och villkorar studenters möjligheter att lära till yrkeslärare i samband med distansundervisning.

\section{Studenternas undervisningspraktik vid undervisning på distans}

Studenternas undervisningspraktik påverkades av behovet att ta hänsyn till de förändrade villkoren för elevernas närvaro i undervisningen. Studenterna tvingades omdefiniera och nyansera för sig själva det som hittills framstod som tämligen oproblematiskt, att elever är närvarande i undervisningen. Från att betrakta elevnärvaro i binära termer, som antingen närvarande eller frånvarande, fick studenterna förhålla sig till synkron samt olika former av asynkron elevnärvaro.

\section{Schemat gav struktur åt studentens undervisning}

Studenternas undervisning påverkades i varierande grad av den hastigt påkomna förändringen. Studenternas anpassning till distansundervisning villkorades av tillgången till de digitala verktyg, exempelvis digitala läromedel som redan var i bruk.

“Digitala läromedel, men annars följde vi schemat exakt och la upp uppgifter som skickades in, redovisningar digitalt liksom föreläsningar, filmer mm. Viss praktisk undervisning digitalt." Övergången till distansundervisning rubbade i sig inte lektionsschemat som stabiliserande: "vi följde schemat". Inte heller förändrades strukturerade relateranden för vem som gör vad i undervisningen, till exempel att både elever och yrkeslärare använder digitala läromedel.

\section{Omdefinierad och individualiserad elevnärvaro och elevaktivitet}

Elevers närvaro blev för studenterna något som de behövde problematisera eftersom omställningen rubbade försanthållande om vad det innebär att vara närvarande i undervisningen som elev. Studenternas undervisningspraktik fick i stället utgå från att eleverna kunde vara närvarande på olika sätt, både synkront och asynkront. Den synkrona elevnärvaron var en utmaning för studenterna 
"Men nu fick man planera om och i den planeringen fick jag vara med!"

som måste ta hänsyn till närvaro i förhållande till att eleverna till exempel sitter på en buss eller är hemma. Närvaro när studenten har en genomgång där eleverna är i skolan är vanligtvis ett förgivettaget villkor, men genom distansundervisningen blev närvaron "på alternativa sätt" starkt kopplad till vad som i stunden var möjligt att göra tillsammans, till exempel närvara genom att lyssna.

Intentioner om att skapa förutsättningar för elever att närvara på distans och med hjälp av digitala medel blev därmed tydliga i studenternas undervisning. "Det jag tar med mig är lättheten att nå elever i fortsättningen. - Kan du inte av olika anledningar vara med på lektionen (tandläkare, buss till läkare mm), så kan du alltid delta på lektion via telefon för att höra, se vad som görs)." I det här fallet synliggörs att studenterna såg distansundervisningen som en möjlighet till att fler elever skulle kunna vara delaktiga och på så sätt ta till sig undervisningen. Med omställningen tvingades studenterna ta större ansvar för att dels möjliggöra för elever att vara närvarande, dels planera för sin undervisning utifrån elevers alternativa sätt att närvara.

\begin{abstract}
Att olika elever får ut mest ut av olika former av undervisning! Det jag mest kommer ta med mig är att distansundervisningen gynnade vissa elever, framför allt de som av någon anledning har svårt att vistas i skolan. Kan vara allt från hemmasittare till de som behandlas för cancer eller av andra anledningar är infektionskänsliga. För första gången fick de ta del av den ordinarie undervisningen. Från och med nu kan ingen skola hävda att man inte kan bedriva fullgod undervisning på distans parallellt med den ordinarie undervisningen.
\end{abstract}

Citatet ovan illustrerar ett påtagligt behov av att individualisera undervisningen med hänsyn tagen till elevers olika sätt att närvara. Differentiering av elevers närvaro tonade fram som en ny realitet för studenterna att hantera, och förstärkte således kraven på studenternas undervisning. De stimulerades redan i planeringen att dels anpassa sin undervisning till elevers individuellt varierande sätt att närvara, dels skapa kontinuitet för elevgruppen med hänsyn till den skiftande närvaron. Graden av kontroll över skeenden i det digitala klassrummet växlade enligt studenterna mellan lärarledda, synkrona och elev-självständiga och därmed lärar-oberoende, asynkrona aktiviteter. Det framstod som vanligt att studenternas undervisning skedde med hjälp av inspelat undervisningsmaterial som följdes upp genom synkrona sessioner. "Gällande distansundervisningen skedde den både synkront och asynkront. Jag lade upp instruktioner i video och text och sedan hade vi diskussionsforum. Vi sågs i fjärrsessioner en till två gånger i veckan."

Det ökade behovet av synkron interaktivitet mellan elever och studenten ställde i sin tur stora krav på studenternas egentillverkade material, vilket eleverna kunde ta del av medan de väntade på att få träffa den undervisande studenten enskilt eller i mindre grupper.

Det har varit svårt att ha alla elever samtidigt i den praktiska delen av undervisningen. Därför har vi haft behov av att fixa olika filmer som eleverna kan använda sig av inför praktiska momentet. För mig som lärare [student anställd som lärare, 
vår anm.] och som har haft behov av att dela klasserna i max 5 personer har det varit ganska ansträngande att behöva upprepa samma lektion 2 gånger per dag och ibland 3 gånger per dag.

Ovanstående citat ger dels uttryck för det tidigare nämnda individualiseringsbehovet som studenterna behövde ta hänsyn till, dels ökat behov av kreativitet. Den högre omfattningen av individualiserad undervisning medförde även fler individuella elevuppgifter som studenterna fick rätta och ge återkoppling på. "Mer egna arbeten för eleverna; Mer arbete för oss lärare [student anställd som lärare, vår anm.] med rättning av inlämningar och prov." Omställningen krävde en medvetenhet om vilken typ av undervisning, synkron eller asynkron, studenterna hade för avsikt att planera och genomföra. När undervisning redan från start behövde planeras som en antingen-eller-aktivitet skärptes kraven på olika hänsynstaganden. Dessa aktualiserades sedan i genomförande- och utvärderingsfasen. Medvetenhet om kategoriseringen av undervisning som antingen synkron eller asynkron skärpte studenternas uppmärksamhet på betydelsen av att ha en genomarbetad undervisningsplanering. Omställningen förändrade och berikade på så sätt studenternas didaktiska och begreppsmässiga tillgångar för undervisning.

Individualisering av undervisningen fick för studenterna en ny innebörd, förutom att handla om skiftande former för elevnärvaro fick de även ta hänsyn till de skiftande individuella behoven. För studenternas del aktualiserade omställningen vikten av individuella anpassningar med mer enskild handledning i förhållande till gruppundervisning.

\footnotetext{
Även för tysta elever i klassrummet har Teams varit mycket bra. I klassrummet kommer de inte till tals eller vill inte säga något i helklass. Nu får de samtal enskilt med läraren och då blir det ett annat samtal. Som lärare får du bra kontakt med dem och de känner sig trygga så samtalen fungerar bra.
}

Här uppmärksammades en stor spännvidd av individualiseringsbehovet, från "tysta elever i klassrummet" som gynnades av individuella samtal via skärm, till de som av olika orsaker uppfattades av studenten som svåra att nå via digital undervisning. " Även de elever som saknar sin motor passar inte för distansundervisning. De behöver komma igång varje lektion och även hjälp att hitta tillbaka om de tappar tråden. Eleven söker inte upp läraren när de inte vet vad de ska göra, utan läraren måste ta kontakten."

\section{Omsorg om tillförlitlig bedömning $i$ studenternas undervisningspraktik}

Mer individualiserad undervisning aktualiserade bedömning som didaktiskt område. När förgivettagna och kanske mer standardiserade sätt att bedöma, till exempel att "se" och bedöma samtliga elevers arbetsprocesser inte längre fungerade, ställdes även tillförlitlighet av bedömning på sin spets. Behovet att stärka validitet i samband med bedömning aktualiserades för studenterna som en didaktisk aspekt. 
"Men nu fick man planera om och i den planeringen fick jag vara med!"

Vi fick utveckla våra bedömningar genom seminarium, muntliga examinationer, spela in film och skriftliga prov i Teams och V-klass. Provsituationen i Teams har varit annorlunda. Svårt att genomföra skriftliga prov och även göra det säkert. Vi har genomfört prov men fått komplettera med muntliga prov där eleven fått förklara och utveckla sin text. Vilket har gett mig en säkrare grund för att göra mina bedömningar.

Centralt för diskussionerna var hur studenterna kunde agera för att få fram varierat bedömningsunderlag. Behovet att skapa ett varierat bedömningsunderlag uppmärksammades när studenterna blev varse om hur olika bedömningsverktyg riskerade att bli mindre tillförlitliga och därför fick kompletteras enligt citatet ovan.

\section{Omsorg för relationellt arbete i studenternas undervisningspraktik}

Studenternas planering, genomförande och utvärdering av undervisning inbegrep även yrkeslärares relationella arbete, till exempel att skapa förtroende, tillit, auktoritet och att stärka elevers välbefinnande. Omställningen riktade på så sätt ett ljus mot relationellt arbete i samband med undervisning. Frågor om hur man som yrkeslärare kan skapa tillit, auktoritet, förtroende, trygghet och välbefinnande samt motivation och engagemang genom distansundervisning kom i förgrunden för studenternas lärande under VFU. Återigen fick förgivettagna sätt att agera ge vika, vilket aktualiserade för studenterna behovet av mer medvetna och preventiva snarare än reaktiva förhållningssätt, till exempel hur kontinuerligt stöd till elever vid distansundervisning kan ges. "Det har varit vid två tillfällen när eleven börjat gråta som Teams har känts som ett hinder; Mer sociala bitar som förändrades. Det blev till exempel svårare att ha motiverande samtal med eleverna i och med distansundervisningen." Studenternas utsagor vittnade om ett ökat behov av att erövra och hävda sin expertis i undervisningen. "Den respekten/pondus jag har 'på golvet' med min yrkeserfarenhet är svår att implementera via nätet." Den säkerhet som studenterna förknippade med sina tidigare yrkeserfarenheter och som fungerade som ett slags kapital eller ingångsvärde i interaktionen med eleverna, ställdes på sin spets vid övergången till distansundervisning. $\mathrm{Nu}$ behövde studenterna hävda sina yrkeskunskaper på nya och mindre förgivettagna sätt än tidigare.

\section{Problematiserade förhållande mellan "yrkesteori och praktik" i studenternas} undervisningspraktik

Omställningen medförde ett uttalat behov av att på ett nytt sätt balansera "yrkesteori" med praktiska övningar. Studenterna fick omvärdera genom att sätta ord på vilka aktiviteter som kunde "räknas som" praktiska snarare än att slentrianmässigt förhålla sig till den yrkespraktiska delen av undervisning. Studenterna blev varse att relationen mellan yrkesteori och praktik i yrkesämnen var något 
förhandlingsbart snarare än något som skulle kunnat tas förgivet. Det blev tydligt för studenterna att vissa färdighetsbaserade övningar fick ersättas av alternativa, men fullvärdiga upplägg:

"Att det går att göra mycket över nätet men inte allt. Kommer använda meet vid fler tillfällen nu; Skapa uppgifter för elever som i möjligaste mån liknade de praktiska uppgifter de skulle utfört i skolan." Somliga studenter uppgav hur de fick använda sin kreativitet för att planera, genomföra och utvärdera undervisning med hjälp av flera digitala redskap. Till exempel kunde filmning av grödornas utveckling ersätta fältvandringar.

\section{Jag fick använda läroplattformen mer och arbeta med quizzar som avstämning ännu mera. Jag använde Skype, Messenger, pim och sms för att kommunicera med ele- verna. Eftersom jag inte kunde gå på fältvandringar filmade jag grödornas utveck- ling. Likaså fick eleverna skicka mer kort på saker i deras närmiljö.}

Ett av studiens fynd visar att studenterna fick friare händer i att planera, genomföra och utvärdera undervisning. Omställningen innebar att studenterna aktivt och kreativt deltog i skapande av nya yrkesämnesdidaktiska metoder. Studenterna gav explicit uttryck för att de hade blivit mer "insläppta $i$ " planering, genomförande och utvärdering av undervisning av sina VFU-handledare eftersom tidigare förgivettagna arbetssätt plötsligt omkullkastades. De fick en möjlighet att vara med och forma det som pågick snarare än att anpassa sig till det redan existerande. Deras handlingsutrymme ökade, vilket stimulerade ett levande samtal med handledare om synliggörande av balansen mellan det som de gemensamt i dagligt tal betraktade som yrkesteori och praktik. Följaktligen kunde ett mer undersökande förhållningssätt till planering, genomförande och utvärdering skönjas i studenternas utsagor. "Jag blev ännu mer delaktig då man mycket mer tillsammans fick planera undervisningen. Mycket av planeringen var ju redan gjort när jag kom ut på min VFU. Men nu fick man planera om och i den planeringen fick jag vara med!" Ovanstående citat illustrerar hur studenten och handledaren tillsammans grep sig an metodiken och formade undervisningsinnehållet med större fokus på oprövade sätt att förhålla sig till integrationen av yrkesteori och praktiska övningar.

Allt gick dock inte att lösa via digitala redskap och emellanåt var det problematiskt att helt ersätta de praktiska lektionsinslagen. "Men det har också givit oss möjligheter att se vilka konsekvenserna blir med en inte helt optimal planering när det gäller att genomföra undervisningen." En bristfällig planering skärpte studentens uppmärksamhet mot konsekvenserna av en sådan, vilket föranledde att behovet av utvärdering synliggjorts som en viktig del av studenternas lärande till att bli yrkeslärare. 
"Men nu fick man planera om och i den planeringen fick jag vara med!"

\section{Handledning i VFU när undervisningen blir distansbaserad}

Resultaten visar att båda parter bidrog till ett undersökande arbetssätt där handledningen fokuserade på didaktiska överväganden samt att relationen förändrades mellan handledare och VFU-student. Omställningen föranledde inledningsvis behov av prioritering, vilket skedde under stark tidspress och allt som inte var akut blev eftersatt. Även handledningen kom i det första akuta skedet i skymundan.

\footnotetext{
Det skedde så sent att vi alla blev tagna på sängen och som restaurangarbetare i över trettio år så är jag van att få min arbetsdag vänd upp och ner. Vi planerade på eftermiddagen, sköt upp det som inte var akut och tog tag i det som måste lösas. Utvärdering av det vi gjorde vart till en början eftersatt men jag kände att vi tog tag i det till slut.
}

Ovanstående citat visar hur handledningen ställdes på sin spets då det blottlades att vardagliga och mer invanda arbetssätt inte längre var aktuella att använda. Det som handledaren kanske tidigare gjort rutinmässigt, till exempel att introducera studenten i välfungerande arbetssätt, fick nu ge vika för mer responsivt handledarskap där inget var givet. Det tvingande behovet av att tänka om och finna nya vägar kom i förgrunden:

"Alla delar förändrades och mitt arbete fick nya perspektiv. Uppgifter som fungerat tidigare behövde jobbas om mm. Därför fick jag en vidare syn och mer erfarenhet som jag kan ge vidare till min VFU-student." Av citatet framgår hur förändringen gav nya erfarenheter till handledaren, till exempel om yrkeslärares behov av att ständigt förnya sin didaktiska repertoar, erfarenheter som i sin tur studenten fick ta del av.

\section{Didaktiska arrangemang får större fokus $i$ handledningen}

Handledare tillsammans med studenter knöt starkare an till didaktiska överväganden. Ett exempel är då handledaren och studenten tog fram nytt digitalt undervisningsmaterial och spelade in ljud och röster till presentationerna "Vi hjälptes åt på många sätt och pratade om hur olika moment kunde genomföras. Vi skapade tillsammans digitala prov/spelade in röst till presentationer". Ovanstående citat ger vid handen att didaktiska överväganden kom i förgrunden i handledningen.

\section{Handledningen blev mer jämbördig}

Den givna rollfördelningen med att handledaren var den som visste mest och som därför var mest erfaren sattes på prov. Situationen innebar att överväganden som berörde handledares egna osäkerheter då det gällde att hantera digitala verktyg, eller att balansera undervisningen mellan yrkesteoretiska och praktiska inslag blev synliggjorda. Då osäkerheterna blottades innebar det att de blev föremål för en gemensam granskning i handledningssamtalet: "Det som var nytt fick vi lära oss tillsammans eftersom jag aldrig hade haft fjärrundervisning förut, t.ex. 
att använda Meet." Genom att till exempel diskutera tekniska detaljer för att få undervisningen på distans att fungera riktades ett tydligt fokus på att lära tillsammans.Studenten kunde få en mer framträdande roll som kunnig och expert in i handledningen. Förutom att relationen mellan handledaren och studenten blev mer jämbördig $i$ en gemensam lärprocess av att bemästra ett nytt digitalt verktyg, fick studenternas kompetens ett erkännande. "Han har självständigt planerat och genomfört egna lektioner. Han har även tillsammans med skolans IT-avdelning hittat en lösning för att kunna använda den fysiska utrustning som finns på skolan via nätet." Studentens initiativrika insats beskrevs av handledaren som värdefull för den aktuella skolan som organisation, vilket förmodas påverka de överväganden som handledaren gjorde i den vardagsnära handledningen.

\section{Handledningen formaliserades}

En vanlig form av handledning är de samtal som förekommer mellan handledare och student i direkt anslutning inför eller efter en lektion. Viktiga tillfällen för den mer spontana handledningen försvann, tillfällen då handledare kunde ställa omedelbara frågor och då studenten fick möjlighet att reflektera över sin undervisning. Dessa mer spontana möten uteblev som tillfällen för direkt återkoppling om undervisningsmetoder och didaktiska spörsmål. "Vid vanlig lektionsundervisning kan det spontant uppstå frågor eller diskussionsområden som för en lärare är oförberedda, detta missas lite vid distansundervisningsformen och utav detta blir det mindre av utvärdering och reflektion av direkt undervisning för den studerande och mig." "Ja, det blev svårare att hantera och ge respons på undervisning." Vid frånvaro av oplanerad spontan handledning i farten ersattes den av mer formaliserade tillfällen för regelrätta samtal. Dessa planerade handledningstillfällen fyllde en viktigt formativ funktion. De innebar möjligheter att relatera, diskutera och till att justera undervisningsinnehåll i nära anslutning till den pågående undervisningen.

\section{Handledning om utebliven social respons från eleverna $i$ undervisningen}

Eftersom elevnärvaro och aktivitet blev annorlunda vid övergången till distansundervisning påverkades även den sociala interaktionen i undervisningssituationen. De små oansenliga tecknen för social samvaro, till exempel nickningar uteblev. För att använda en av handledarnas formuleringar: "Är det en föreläsning så stirrar alla på en Power Point och det kommer ingen respons från eleverna." Frånvaron av förgivettagna tecknen för interaktion i undervisningen skapade frustration för studenterna enligt handledare. Därför övervägde handledare behovet av att förbereda studenten för hur annorlunda den sociala interaktionen blir då den sker via en dataskärm, i stället för platsförlagd undervisning. Den bristande interaktionen var ett inslag som krävde att handledare behövde lägga mer tid och omsorg på att förbereda studenter för hur de skulle kunna hantera 
"Men nu fick man planera om och i den planeringen fick jag vara med!"

undervisningen utan att känna sig misslyckade. "Där hade jag som handledare en viktig roll att förklara att även jag får ingen stor respons från eleverna."

Det är svårt för studenterna att komma in en klass när undervisningen är på distans. Det skapas inga sociala kontakter vid distansundervisning, eleverna är ofta tysta. Är det en föreläsning så stirrar alla på en Power Point och det kommer ingen respons från eleverna. Där har jag som handledare en viktig roll att förklara att även jag får ingen stor respons från eleverna.

Citaten visar hur handledare övervägde, och identifierade på så sätt behovet att för studenten begripliggöra utebliven elevrespons vid omdefinierad elevnärvaro och elevaktivitet.

\section{Fördjupad analys och slutsatser}

Trots att övergången till distansundervisning innebar en förändring i de kulturella-diskursiva, materiella-ekonomiska och de sociala-politiska arrangemangen så hölls de två samspelande praktikerna, undervisning och handledning, ihop med hjälp av lektionsschemat och handledningsuppdraget. De säganden, göranden och relateranden som således iscensattes i de båda praktikerna gav kontinuitet och stabilitet åt arbetet när villkoren hastigt förändrades. De materiella-ekonomiska och sociala-politiska arrangemangen gav således möjligheter för studenter att lära till yrkeslärare och ramade in handledning som uppdrag i yrkeslärarutbildningen.

Den omdefinierade och individualiserade elevnärvaron medförde större fokus på didaktiska överväganden när det gäller handledning, men även på studenternas planering, genomförande och utvärdering av undervisning. Det semantiska rummet som finner ett uttryck i de här kulturella-diskursiva arrangemangen berikades med synkron och asynkron elevnärvaro som en viktig aspekt av undervisning. Göranden som uttryck för materiella-ekonomiska arrangemang konkretiserades genom handledares och studenters förutsättningslösa prövande och experimenterande av olika digitala strategier och medel. Digitala verktyg genom sin materialitet möjliggjorde förändring i relateranden som pågick mellan studenterna, eleverna och handledarna. Göranden med hjälp av digitala verktyg möjliggjorde diskussioner, grupparbeten, problemlösning, verbalisering och visualisering, planering av undervisning och handledning. Samtidigt som hantering av digitala verktyg lärande blev något som ändrades diskursivt (säganden) blev det ett viktigt innehåll i de relationer som utvecklades under VFU mellan studenterna och handledarna. Att tillsammans behöva handha och iscensätta undervisning av yrkespraktiska moment med hjälp av digitala verktyg blev ett gemensamt intresse för student och handledare. Genom att sammanföra både studenternas och handledarnas uppmärksamhet skapades en mer jämbördig relation mellan parterna. Digitala verktyg som materiella-ekonomiska resurser strukturerade på så vis handledningen och de specifika relateranden som handledning skapade vid omställningen. Det sociala-politiska arrangemanget 
som upprätthöll handledningspraktiken förändrades i riktning mot mer jämbördiga och solidariska förhållanden mellan handledare och den handledde. Yrkesdidaktiska överväganden som säganden och göranden fick uttryckligen mer fokus på att tillsammans utveckla yrkesämnesundervisning på distans. Tillsammans omförhandlade studenterna och handledarna olika förgivettagande om handledning, liksom behovet av att integrera yrkesteori och praktik i yrkeslärares praxis. Med lektionsschemat och handledningsuppdraget som stabiliserande för säganden, göranden och relateranden öppnades ett utrymme för solidariska, mer jämbördiga undersökande och prövande arbetssätt.

\section{Diskussion}

Studien genomförs i samband med en kritisk situation där skolförlagd undervisning i gymnasieskola och kommunal vuxenutbildning förflyttas till hemmet eller annan plats som eleven själv väljer. Det innebär att den distansbaserade undervisningen får betydelse för yrkeslärarstudentens undervisningspraktik i VFU, samt för handledarens uppdrag att skapa förutsättningar för studentens utbildning. För utbildningar som inte redan använder distansundervisning i någon form, skapas nu en helt ny undervisningspraktik där det till synes givna och vardagliga behöver planeras, organiseras och genomföras på ett helt nytt sätt, med stöd av befintliga digitala verktyg i nya användningsområden eller nya digitala verktyg för att hantera identifierade behov (Basilaia \& Kvavadze, 2020; Bergdahl \& Nouri, 2020). Såväl undervisning som handledning i VFU förändras. Det innebär att den yrkespraktik som utgör referens i yrkeslärarprogrammet via både studenter och lärares kunskaper utmanas. Sepulveda-Escobar och Morrison (2020) diskuterar betydelsen av att lärarutbildningens innehåll behandlar den faktiska yrkespraktik som studenter möter under sin VFU. Det kan gälla distansundervisning på grund av pågående pandemi, men det kan också gälla andra typer av förändringar eller variationer där studenten bör ges möjlighet att kunna fördjupa sina erfarenheter under och efter avslutad VFU.

Det finns en klassisk kritik mot att lärarutbildningar inte alltid är i takt med samhällsutvecklingen (till exempel Sveriges kommuner och regioner, 2019). Den förändring som nu sker inom handlednings- och undervisningspraktikerna kan ses som en tillfällig parentes, men sannolikt kommer den att bidra till en mer medveten anpassning till den yrkeslärarpraktik som aktualiseras genom lärarutbildningens verksamhetsförlagda del (se t.ex. Adedoyin \& Soykan, 2020; DarlingHammond \& Hyler, 2020).

Genom att förväntningar synliggörs och utmanas förändras också samarbete, kommunikation mellan student och handledare samt innehållet för handledningen. Studiens resultat visar hur studenter tar plats som en kompetent motpart och expert i handledningssammanhang där yrkesdidaktiska spörsmål utgör fokus. VFU-handledaren är expert på vissa områden medan studenten bidrar med 
"Men nu fick man planera om och i den planeringen fick jag vara med!"

nya kunskaper som handledaren i sin tur utmanas att lyfta fram i handledningen. Handledningen kan därför uppfattas som inbyggd i planeringen, genomförandet och uppföljningen av både studenten och handledarens undervisning dvs. handledningen blir tätare ihopkopplad med undervisningen. Betydelsen av att hjälpas åt med kreativa idéer, befintliga kunskaper om digital teknik och undervisningsmaterial leder således till behov av samarbete där handledning dels får både karaktär av att hjälpas åt med det gemensamma, dels att stötta varandra i det vardagliga ständigt pågående förändringsarbetet.

Både det planerade, till exempel synkron undervisning och det oplanerade, till exempel individuella elevers synkrona närvaro behöver hanteras gemensamt. De yrkesämnesdidaktiska frågorna om hur en likvärdig undervisning kan skapas genom t ex individualisering är ständigt återkommande och aktualiseras nu i ett nytt ljus vid övergången till distansundervisning. Likaså uppmärksammas frågor om relationen mellan yrkesteori och praktik och då inte endast i relation till den kontextuella inramningen av nationell krishantering utan också som en del av utvecklingen inom yrkesämnesdidaktik. Det kan dock finnas en risk att det för dagen aktuella och pressande i situationen tar överhanden. Det innebär att de moment som ska behandlas i studentens VFU, till exempel pedagogisk bedömning, inte blir helt framträdande vilket kan få konsekvenser för studentens utbildning.

Artikelns resultat visar att hybridundervisning är på väg att normaliseras inom utbildning (Adedoyin \& Soykan, 2020). Det som i det första skedet verkade tillfälligt kan numera bli det normala, och vi vill gå så långt som att säga att det rör sig om ett paradigmskifte inom yrkeslärarutbildningen. Det behövs ökad medvetenhet och beredskap för att handleda i hybridundervisning vilket föranleder behovet av att anpassa yrkeslärarutbildningen och kompetensutveckla såväl handledare som VFU-kurslärare. Distansundervisningen ställer nya frågor som har sin utgångspunkt i reella didaktiska behov i stället för i det som den digitala tekniken erbjuder (Andreasson \& Dovemark, 2013; Palak \& Walls, 2014; Player-Koro, 2018; Williamson m.fl., 2020). Om lärares identifierade behov ställer krav på och styr utvecklingen av digitala lösningar i undervisningen skapas en ny balans mellan utveckling av digitala verktyg och användbarhet.

För att utveckla lärarkompetens i samband med VFU behöver studenten få direkt tillgång till VFU-handledarens praktik. Via handledning kan studenten få syn på och ges möjlighet att diskutera bakgrund och argument för didaktiska val, samt få återkoppling på sin egen prestation. Under förutsättning att det finns goda möjligheter till övning och uppföljning av såväl undervisning som övriga arbetsuppgifter som kan relateras till uppdraget som yrkeslärare, formar och formas studenten mot en grundläggande yrkesläraridentitet och skicklighet.

Utifrån ett litet empiriskt underlag behöver resultaten betraktas som tentativa. Det är främst rutinerade VFU-handledare som träder fram i studien medan erfarenheter av de som är mindre förtrogna med handledaruppdraget inte är lika 
synliga. Av enkätsvaren att döma hade över $80 \%$ av handledarna tidigare handlett och hälften av dem hade gått handledarutbildning. Enkätens utformning ger inte möjlighet att dra några slutsatser om relationen mellan olika former av handledarutbildning och VFU-handledarnas samlade erfarenhet och beredskap att anpassa handledning efter situationens behov. Varken handledning eller studenternas lärande i en specifik kontext av kommunal vuxenutbildning belyses i lika stor utsträckning som ungdomsskola eftersom cirka $80 \%$ av handledarna uppgav att de huvudsakligen undervisar ungdomar. Ungefär hälften av studenterna gjorde VFU i egen tjänst, vilket föranleder ett vidare intresse för hur erfarenhet av att undervisa och handledas kan skilja sig mellan studenter som redan är yrkesverksamma i skolan, och de som inte har en anställning som yrkeslärare. Att i sin dagliga verksamhet kombinera två roller, yrkeslärarstudentens och yrkeslärares, kan påverka de svar som vi fick.

Vi som forskare i föreliggande studie är i våra olika roller delaktiga i och ansvariga för att forma handledningsuppdraget som en del av yrkeslärarutbildningen. Tillsammans bidrar våra olika perspektiv till att skapa förutsättningar för blivande yrkeslärare då undervisningens och handledningens praktikarkitekturer förändras. Det gäller inte bara studenters egen utveckling inom VFU utan också utveckling av lärarkompetens i ett större lärandesammanhang. På så sätt blir studenterna förberedda på en föränderlig utbildning i sitt framtida yrkesliv och får verktyg för att beredas inför det systematiska kvalitetsarbetet i rollen som yrkeslärare (Kalloo m.fl., 2020; van der Spoel m.fl., 2020). Avslutningsvis vill vi peka på behovet av att ansvariga parter, i dialog, utvecklar handledaruppdraget, såväl som lärarutbildningen som helhet i samklang med samhällsutvecklingen.

\section{Om författarna}

Martina Wyszynska Johansson är universitetslektor vid Institutionen för pedagogik och specialpedagogik vid Göteborgs universitet. Martinas forskningsintresse är arbetsintegrerat lärande i lärarutbildningar, utveckling av lärares professionskunskap och yrkeselevers upplevda läroplan. Hon undervisar i yrkeslärarutbildningen.

Ellinor Dyne är filosofie licentiat i pedagogik och arbetar som utvecklingsledare vid Utbildningsförvaltningen/HR och kommunikation i Göteborg. Ellinors forskningsintresse är organisation och ledarskap för gymnasiala yrkesutbildningar. Likaså har hon, på både strukturell och lokal nivå, arbetat med organisation för och integration av hela skolans arbete med studie- och yrkesvägledning. Ellinor är förvaltningsgemensam samordnare för VFU-frågor. 
"Men nu fick man planera om och i den planeringen fick jag vara med!"

Susanne Gustavsson är universitetslektor i pedagogik vid Institutionen för pedagogik och specialpedagogik vid Göteborgs universitet. Hennes forskningsområden är yrkesutbildningens undervisningspraktik och yrkeslärande i skola och på arbetsplats samt skolutveckling och företrädesvis praktiknära studier och projekt. Hon undervisar i yrkeslärarutbildningen. 


\section{Referenser}

Adedoyin, O. B. \& Soykan, E. (2020) Covid-19 pandemic and online learning: The challenges and opportunities. Interactive Learning Environments. https:/ / doi.org/10.1080/10494820.2020.1813180

Andreasson, I. \& Dovemark, M. (2013). Transforming insecurity into a commodity: Using the digital tools Unikum and InfoMentor as an example in Swedish education. European Educational Research Journal, 12(4), 480-491. https:/ / doi.org/10.2304/eerj.2013.12.4.480

Basilaia, G. \& Kvavadze, D. (2020). Transition to online education in schools during a SARS-CoV-2 coronavirus (COVID-19) pandemic in Georgia. Pedagogical Research, 5(4), em0060. https:/ / doi.org/10.29333/pr/7937

Bergdahl, N. \& Nouri, J. (2020). Covid-19 och omställning till distansundervisning $i$ svensk skola: Återföringsrapport. Stockholms universitet. https://www.ifous.se/app/uploads/2020/03/COVID19-omstllningen-tilldistansundervisning.pdf

Carrillo, C. \& Flores, M. A. (2020). COVID-19 and teacher education: A literature review of online teaching and learning practices. European Journal of Teacher Education, 43(4), 466-487. https:/ / doi.org/10.1080/02619768.2020.1821184

Darling-Hammond, L. \& Hyler, M. E. (2020) Preparing educators for the time of COVID ... and beyond. European Journal of Teacher Education, 43(4), 457-465. https:/ / doi.org/10.1080/02619768.2020.1816961

Enochsson, A.-B., Kilbrink, N., Andersén, A. \& Ådefors, A. (2020). Connecting school and workplace with digital technology: Teachers' experiences of gaps that can be bridged. Nordic Journal of Vocational Education and Training, 10(1), 43-64. https:/ / doi.org/10.3384/njvet.2242-458X.2010143

Fransson, G., Holmberg, J., Lindberg, O. J. \& Olofsson, A. D. (2019). Digitalise and capitalise? Teachers' self-understanding in 21st-century teaching contexts. Oxford Review of Education 45(1), 102-118.

https://doi.org/10.1080/03054985.2018.1500357

Gustavsson, S., Messina Dahlberg, G. \& Berglund, I. (2020). Digitala körsimulatorer i yrkesutbildning: Utmaningar och möjligheter. Nordic Journal of Vocational Education and Training, 10(1), 108-136.

https:/ / doi.org/10.3384/njvet.2242-458X.20101108

Henning Loeb, I. \& Windsor, S. (2020). Online-and-alone (och ofta i sängen): Elevers berättelser om gymnasietidens sista månader våren 2020. Paideia, (20), 39-51.

Kalloo, R. C., Mitchell, B. \& Kamalodeen, V. J. (2020). Responding to the COVID19 pandemic in Trinidad and Tobago: Challenges and opportunities for teacher education. Journal of Education for Teaching, 46(4), 452-462. https:/ / doi.org/10.1080/02607476.2020.1800407 
"Men nu fick man planera om och i den planeringen fick jag vara med!"

Kemmis, S. \& Grootenboer, P. (2008). Situating praxis in practice. I S. Kemmis \& T. J. Smith (Red.), Enabling praxis: Challenges for education (s. 37-62). Sense.

Kemmis, S., Wilkinson, J., Edwards-Groves, C., Hardy, I., Bristol, L. \& Grootenboer, P. (2014). Changing practices: Changing education. Springer Education.

Mahon, K., Francisco, S. \& Kemmis, S. (2017). Exploring education and professional practice: Through the lens of practice architectures. Springer.

Kidd, W. \& Murray, J. (2020). The Covid-19 pandemic and its effects on teacher education in England: How teacher educators moved practicum learning online. European Journal of Teacher Education, 43(4), 542-558. https:/ / doi.org/10.1080/02619768.2020.1820480

Murray, C., Heinz, M., Munday, I., Keane, E., Flynn, N., Connolly, C., Hall T. \& MacRuairc, G. (2020). Reconceptualising relatedness in education in 'distanced' times. European Journal of Teacher Education, 43(4), 488-502. https:/ / doi.org/10.1080/02619768.2020.1806820

Palak, D. \& Walls, R. T. (2014). Teachers' beliefs and technology practices: A mixed-methods approach. Journal of Research on Technology in Education, 41(4), 417-441. https:/ / doi.org/10.1080/15391523.2009.10782537

Player-Koro, C., Bergviken Rensfeldt, A. \& Selwyn N. (2018). Selling tech to teachers: Education trade shows as policy events. Journal of Education Policy, 33(5), 682-703. https:/ / doi.org/10.1080/02680939.2017.1380232

Player-Koro, C. (2018). Skolans digitalisering. Ett kritiskt perspektiv. I Ulla Carlsson (Red.). Medie- och informationskunnighet (MIK) $i$ den globala tidsåldern: en demokratifråga: kartläggning, analys, reflektioner. Nordicom.

Regeringen. (2017). Nationell digitaliseringsstrategi för skolväsendet. Regeringskansliet.

Russo, T. \& Benson, S. (2005). Learning with invisible others: Perceptions of online presence and their relationship to cognitive and affective learning. Journal of Educational Technology \& Society, 8(1), 54-62.

http:/ / www.jstor.org/stable/jeductechsoci.8.1.54

Rönnerman, K. (2018). Vikten av teori i praktiknära forskning: Exemplet aktionsforskning och teorin om praktikarkitekturer. Utbildning $\mathcal{E}$ Lärande 12(1), 41-54. http://du.diva-portal.org/smash/get/diva2:1271708/FULLTEXT01.pdf

Sangeeta \& Tandon, U. (2020). Factors influencing adoption of online teaching by school teachers: A study during COVID -19 pandemic. Journal of Public Affairs, E2503. https://doi.org/10.1002/ pa.2503

Selwyn, N., Nemorin, S., Bulfin, S. \& Johnson, N. (2017). Left to their own devices: The everyday realities of one-to-one classrooms. Oxford Review of Education, 43(3), 289-310. https:/ / doi.org/10.1080/03054985.2017.1305047 
Sepulveda-Escobar, P. \& Morrison, A. (2020) Online teaching placement during the COVID-19 pandemic in Chile: Challenges and opportunities. European Journal of Teacher Education, 43(4), 587-607. https://doi.org/10.1080/02619768.2020.1820981

Sjølie, E., Francisco, S., Mahon, K., Kaukko, M. \& Kemmis, S. (2020). Learning of academics in the time of the coronavirus pandemic. Journal of Praxis in Higher Education, 2(1), 85-107.

Stenliden, L., Martin Bylund, A., Landkvist, L., Ekström Lind L., Kellgren Lundberg, S., Stenmark, H. \& Wilhelmsson, C. (2020). Lärares digitala kompetens före, under och efter covid-19. SocArXiv.

Sveriges kommuner och regioner. (2019). \#skolDigiplan. Nationell handlingsplan för digitalisering av skolväsendet.

Sveriges Riksdag. (2015). Digitaliseringen i skolan: Dess påverkan på kvalitet, likvärdighet och resultat $i$ utbildningen (2015/16: RFR18).

Tu, C.-H. \& McIsaac, M. (2002). The relationship of social presence and interaction in online classes. American Journal of Distance Education, 16(3), 131-150. https://doi.org/10.1207/S15389286AJDE1603_2

Utbildningsdepartementet. (1999). Att lära och leda: En lärarutbildning för samverkan och utveckling (SOU 1999:63). Utbildningsdepartementet.

Utbildningsdepartementet. (2008). En hållbar lärarutbildning (SOU 2008:109). Utbildningsdepartementet.

Utbildningsutskottet. (2016). Digitalisering $i$ skolan: Dess påverkan på kvalitet, likvärdighet och resultat $i$ utbildningen. Sveriges riksdag.

van der Spoel, I., Noroozi, O., Schuurink, E. \& van Ginkel, S. (2020) Teachers' online teaching expectations and experiences during the covid19-pandemic in the Netherlands. European Journal of Teacher Education, 43(4), 623-638. https://doi.org/10.1080/02619768.2020.1821185

Williamson, B., Eynon, R. \& Potter, J. (2020) Pandemic politics, pedagogies and practices: Digital technologies and distance education during the coronavirus emergency. Learning, Media and Technology, 45(2), 107-114. https://doi.org/10.1080/17439884.2020.1761641

Zhou, L., Li, F., Wu, S. \& Zhou, M. (2020). 'School's out, but class's on', the largest online education in the world today: Taking China's practical exploration during the covid-19 epidemic prevention and control as an example. Best Evidence in Chinese Education, 4(2), 501-519. 